\title{
Synthesis of Metallacyclobutenes of Late Transition Metals via Nucleophilic Addition of Allenyl or Propargyl Complexes
}

\author{
Yuan-Chung Cheng, Yu-Kun Chen, Tsang-Miao Huang, Chao-Ining Yu, \\ Gene-Hsiang Lee, Yu Wang, and J wu-Ting Chen* \\ Department of Chemistry, National Taiwan University, Taipe, Taiwan 106, Republic of China
}

Received October 6, 1997

\begin{abstract}
The regioselective addition of $\mathrm{NEt}_{3}, \mathrm{PPh}_{3}$, or pyridine to the central carbon of a cationic $\eta^{3}$-allenyl/propargyl complex of platinum, $\left\{\mathrm{Pt}\left(\mathrm{PPh}_{3}\right)_{2}\left(\eta^{3}-\mathrm{C}_{3} \mathrm{H}_{3}\right)\right\}\left(\mathrm{BF}_{4}\right)(\mathbf{1})$, leads to the formation of the new cationic platinacyclobutenes $\left\{\left(\mathrm{PPh}_{3}\right)_{2} \mathrm{Pt}\left[\mathrm{CH}_{2} \mathrm{C}(\mathrm{Nu}) \mathrm{CH}\right]\right\}\left(\mathrm{BF}_{4}\right)\left(\mathrm{Nu}=\mathrm{NEt}_{3}(\mathbf{2 a})\right.$, $\mathrm{PPh}_{3}(\mathbf{2 b}), \mathrm{C}_{5} \mathrm{H}_{5} \mathrm{~N}(\mathbf{2 c})$ ) via formation of a $\mathrm{C}-\mathrm{N}$ or $\mathrm{C}-\mathrm{P}$ bond, respectively. Complex $\mathbf{2 c}$ can transform into $\left\{\mathrm{cis}-\mathrm{Pt}\left(\mathrm{PPh}_{3}\right)_{2}(\mathrm{Py})\left(\eta^{1}-\mathrm{CHCCH}_{2}\right)\right\}\left(\mathrm{BF}_{4}\right)(3)$. The rever se reaction has not been observed. It is suggested that nucleophilic addition of $\mathbf{1}$ likely involves external attack at the central carbon of the $\eta^{3}$-allenyl/propargyl ligand. Protonation of $\mathbf{2} \mathbf{b}$ yields $\left\{\mathrm{Pt}\left(\mathrm{PPh}_{3}\right)_{2^{-}}\right.$ $\left.\left[\eta^{3}-\mathrm{CH}_{2} \mathrm{C}\left(\mathrm{PPh}_{3}\right) \mathrm{CH}_{2}\right]\right\}\left(\mathrm{BF}_{4}\right)_{2}(7)$. Addition of $\mathrm{PPh}_{3}$ to a labile $\eta^{1}$-allenyliridium complex, (OC6-42)-Ir(Cl)(PPh $)_{2}(\mathrm{OTf})(\mathrm{CO})\left(\eta^{1}-\mathrm{CHCCH}_{2}\right)(4)$, results in the iridacyclobutene $\left\{(\mathrm{Cl})\left(\mathrm{PPh}_{3}\right)_{2}-\right.$ (CO) $\left.r\left[\mathrm{CH}_{2} \mathrm{C}\left(\mathrm{PPh}_{3}\right) \mathrm{CH}\right]\right\}$ (OTf) (5). The single-crystal X-ray structure of $\mathbf{5}$ has been determined.
\end{abstract}

\section{Introduction}

Metallacyclobutenes are important organometallic species that are involved in processes of metathesis ${ }^{1}$ and polymer synthesis. ${ }^{2}$ Tebbe, Parshall, and their coworkers led this field with studies of titanacyclobutenes. ${ }^{3}$ Other workers have developed coupling reactions between metal carbene complexes and acetylenes as a useful route to such compounds (Scheme 1).4,5 Metallacycl obutenes of late transition metals were unknown until Semmelhack et al. prepared ferracyclobutenes using the same approach. ${ }^{6}$ These studies were extended later to the preparation of metallacyclobutenes of cobalt, rhodium, iridium, and platinum. ${ }^{7}$

A new synthetic route, the addition of soft nucleophiles to a cationic $\eta^{3}$-allenyl/propargyl rhenium complex to give a rhenacycl obutene complex, was reported by Casey and co-workers. ${ }^{8}$ We and others have independently developed the addition reactions of cationic $\eta^{3}$-allenyl/propargyl complexes of the late transition metals as a route to central-carbon-substituted $\eta^{3}$-allyl

(1) (a) Tebbe, F. N.; Parshall, G. W.; Reddy, G. S. J . Am. Chem. Soc 1978, 100, 3611. (b) Grubbs, R. H. Prog. Inorg. Chem. 1978, $24,1$.

(2) (a) Grubbs, R. H.; Tumas, W. Science 1989, 243, 907 and references therein. (b) Fox, H. H.; Wolf, M. O.; O'Dell, R.; Lin, B. L.; Schrock, R. R.; Wrighton, M. S. J. Am. Chem. Soc. 1994, 116, 2827 and references therein.

(3) Tebbe, F. N.; Parshall, G. W.; Ovenall, D. W. J . Am. Chem. Soc. $1979,101,5074$

(4) Tebbe, F. N.; Harlow, R. L. J . Am. Chem. Soc. 1980, 102, 6149. (5) McKinney, R. J .; Tulip, T. H.; Thorn, D. L.; Coolbaugh, T. S.; Tebbe, F. N. J. Am. Chem. Soc. 1981, 103, 5584.

(6) (a) Semmel hack, M. F.; Tamura, R.; Schnatter, W.; Springer, J J. Am. Chem. Soc. 1984, 106, 5363. (b) Wakatsuki, Y.; Miya, S.; Yamazaki, H.; I kuta, S. J . Chem. Soc., Dalton Trans. 1986, 1201. (c) Lisko, J . R.; J ones, W. M. Organometallics 1985, 4, 944. (d) Conti, N. J.; J ones, W. M. Organometallics 1988, 7, 1666. (e) Conti, N. J .; Croether, D. J .; Tivakornpannarai, S.; J ones, W. M. Organometallics 1990, 9, 175.

\section{Scheme 1}

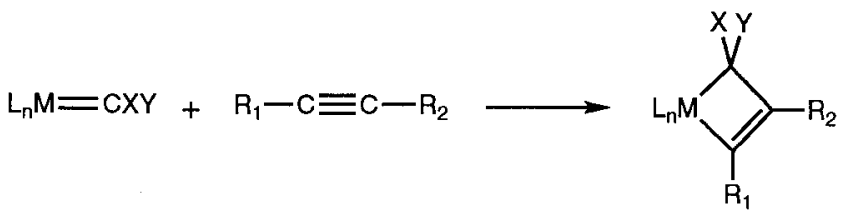

complexes, $\eta^{3}$-trimethylenemethane complexes, and $\eta^{3}$ oxa- and $\eta^{3}$-azatrimethylenemethane complexes. ${ }^{9}$ Den-

(7) For a review: (a) J ennings, P. W.; J ohnson, L. L. Chem. Rev. 1994, 94, 2241. For Co: (b) Wakatsuki, Y.; Miya, S.; Y amazaki, H. J Chem. Soc., Dalton Trans. 1986, 1201. (c) O'Connor, J. M.; J i, H.-L.; Iranpour, M.; Rheingold, A. L. J . Am. Chem. Soc. 1993, 115, 1586. (d) O'Connor, J. M.; J i, H.-L.; Rheingold, A. L. J . Am. Chem. Soc. 1993 115, 9846. (e) O'Connor, J. M.; Fong, B. S.; J i, H.-L.; Hiibner, K.; Rheingold, A. L.J. Am. Chem. Soc. 1995, 117, 8029. For Rh: (f) Fisch, P. D.; Khare, G. P. J . Organomet. Chem. 1977, 142, C61. (g) Werner, H.; Heinemann, A.; Windmüller, B.; Steinert, P. Chem. Ber. 1996, 129, 903. For Ir: (h) Tuggle, R. M.; Weaver, D. L. Inorg. Chem. 1972, 11, 2237. (i) Calabreses, J. C.; Roe, D. C. Thorn, D. L.; Tulip, T. H. Organometallics 1984, 3, 1223. (j) O'Connor, J. M.; Pu, L.; Woolard, S.; Chadha, R. K. J . Am. Chem. Soc. 1990, 112, 6731. (k) Burgess, J.; Kemmit, R. D. W.; Morton, N.; Mortimer, C. T.; Wilkinson, M. P. J. Organomet. Chem. 1980, 191, 477. (I) Forcolin, S.; Pellizer, G.; Graziani, M.; Lenarda, M.; Ganzerla, R. J . Organomet. Chem. 1980, 194, 203. (m) Hemond, R. C.; Hughes, R. P.; Robinson, D. J .; Rheingold, A. L. Organometallics 1988, 7, 2239. (n) Hughes, R. P.; King, M. E.; Robinson, D. J .; Spotts, J . M. J . Am. Chem. Soc. 1989, 111, 8919.

(8) (a) Casey, C. P.; Y i, C. S. J. Am. Chem. Soc. 1992, 114, 6597. (b) Casey, C. P.; Nash, J. R.; Yi, C. S.; Selmeczy, A. D.; Chung, S.; Powell, D. R.; Hayashi, R. K. J . Am. Chem. Soc. 1998, 120, 722.

(9) (a) Huang, T.-M.; Chen, J .-T.; Lee, G.-H.; Wang, Y.J . Am. Chem Soc. 1993, 115, 1170. (b) Baize, M. W.; Furilla, J . L.; Wojcicki, A. Inorg. Chim. Acta 1994, 233, 1. (11) (c) Plantevin, V.; Blosser, P. W.; Gallucci, J. C.; Wojcicki, A. Organometallics 1994, 13, 3651. (d) Baize, M. W. Plantevin, V.; Gallucci, J . C.; Wojcicki, A. Inorg. Chim. Acta 1995, 235, 1. (e) Ogoshi, S.; Tsutsumi, K.; Kurosawa, H. J . Organomet. Chem. 1995, 493, C19. (f) Ogoshi, S.; Tsutsumi, K.; Ooi, M.; Kurosawa, H. J. Am. Chem. Soc. 1995, 117, 10415. (g) Baize, M. W.; Blosser, P. W.; Plantevin, V.; Schimpff, D. G.; Gallucci, J . C.; Wojcicki, A. Organome tallics 1996, 15, 164. (h) Tsai, F.-Y.; Chen, J .-T.; Lee, G.-H.; Wang, Y. J . Organomet. Chem. 1996, 520, 85. 
Scheme 2

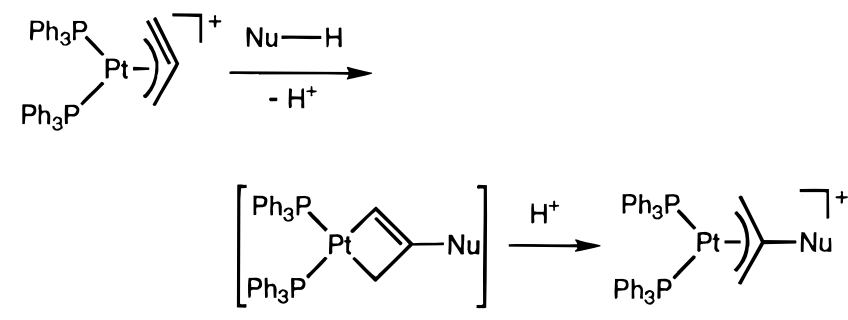

Scheme 3

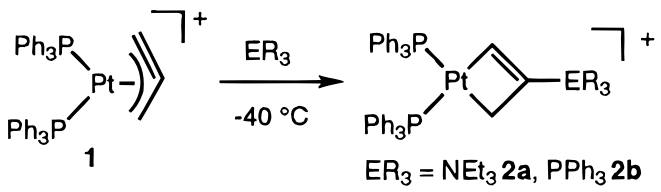

sity functional caculations indicate that metallacyclobutenes are likely the kinetic intermediates in such addition reactions (Scheme 2). ${ }^{10}$ We report here the first examples of the synthesis of platina- and iridacyclobutene complexes via addition of nitrogen- and phosphorus-centered nucl eophiles to either ( $\eta^{1}$-allenyl)or ( $\eta^{3}$-allenyl/propargyl)metal complexes.

\section{Results and Discussion}

The reactions of the ( $\eta^{3}$-allenyl/propargyl)platinum complex $\left\{\mathrm{Pt}\left(\mathrm{PPh}_{3}\right)_{2}\left(\eta^{3}-\mathrm{C}_{3} \mathrm{H}_{3}\right)\right\}\left(\mathrm{BF}_{4}\right)(\mathbf{1})$ with an equimolar amount of $\mathrm{Et}_{3} \mathrm{~N}$ or $\mathrm{Ph}_{3} \mathrm{P}$ in chloroform or methylene dichloride at $-40{ }^{\circ} \mathrm{C}$ readily gave the cationic platina-

cycl obutene complexes $\left\{\left(\mathrm{PPh}_{3}\right)_{2} \mathrm{Pt}\left[\mathrm{CH}_{2} \mathrm{C}(\mathrm{Nu}) \mathrm{CH}\right]\right\}\left(\mathrm{BF}_{4}\right)$ $\left(\mathrm{Nu}=\mathrm{NEt}_{3}(\mathbf{2 a}), \mathrm{PPh}_{3}(\mathbf{2 b})\right)$ (Scheme 3). Complex 2a decomposes on drying in vacuo, presumably due to evaporation of $\mathrm{Et}_{3} \mathrm{~N}$. We have characterized $\mathbf{2 a}$ by NMR spectroscopy. Complex $\mathbf{2 b}$ is more stable and has been isolated by crystallization below $0{ }^{\circ} \mathrm{C}$.

The two magnetically nonequivalent phosphine ligands of $\mathbf{2 a}$ or $\mathbf{2} \mathbf{b}$ suggest that these complexes have a cis square-planar configuration. The carbon-bound phosphorus in $\mathbf{2 b}$ shows smaller values of J $\mathrm{p}-\mathrm{pt}(703.8 \mathrm{~Hz})$ compared to those of the $\mathrm{Pt}$-bound $\mathrm{Ph}_{3} \mathrm{P}$ ligands $(\mathrm{J} \mathrm{P}-\mathrm{Pt}$ $=2115,2226 \mathrm{~Hz}$ ). In the ${ }^{1} \mathrm{H}$ NMR spectra, the methylene protons, unlike the diastereotopic protons in rhenacycl obutenes, ${ }^{8}$ give rise to one characteristic resonance at high field, $\delta 0.03(\mathrm{~J} \mathrm{H}-\mathrm{P}=81.9 \mathrm{~Hz}, \mathrm{~J} \mathrm{H}-\mathrm{Pt}=81.9$ $\mathrm{Hz}$ ) for $2 \mathrm{a}$ and $\delta 0.18(\mathrm{~J} \mathrm{H-H}=4.7 \mathrm{~Hz}, \mathrm{~J} \mathrm{H}-\mathrm{P}=81.9 \mathrm{~Hz}$, $J_{H-P t}=85.8 \mathrm{~Hz}$ ) for $\mathbf{2} \mathbf{b}$. The equivalency of the hydrogens of the Pt-bound $\mathrm{CH}_{2}$ suggest that the metallacycle overlaps with the molecular plane and bisects $\angle \mathrm{H}-\mathrm{C}-\mathrm{H}$. Similar NMR features have been found previously for other metallacyclobutenes. ${ }^{3-8}$ The methine resonance of $\mathbf{2 a}$ is found at $\delta 6.01(\mathrm{~J} \mathrm{H}-\mathrm{Pt}=25.9 \mathrm{~Hz}$ ). For $\mathbf{2 b}$, this resonance is in the region of the phenyl signals and was detected by $2 \mathrm{D} \mathrm{H}-\mathrm{H}$ and $\mathrm{C}-\mathrm{H}$ COSY. The ${ }^{13} \mathrm{C}$ NMR resonances for the $\mathrm{Pt}-\mathrm{CH}_{2}$ carbons are also at high field, $\delta-6.07(\mathrm{~J} \mathrm{C-Pt}=79.4 \mathrm{~Hz})$ for $2 \mathbf{a}$ and $\delta-12.6(\mathrm{~J} \mathrm{c-Pt}=83.5 \mathrm{~Hz})$ for $\mathbf{2 b}$. The olefinic carbons appear at $\delta 123.1$ and 142.2 for $\mathbf{2 a}$ and at $\delta 136.3$ and 161.1 for $\mathbf{2 b}$.

The reaction of 1 and pyridine at $-40{ }^{\circ} \mathrm{C}$ immediately resulted in the formation of metastable $\left\{\left(\mathrm{PPh}_{3}\right)_{2^{-}}\right.$

(10) Cheng, Y.-C.; Chen, J .-T.; Gin, B.-Y. Unpublished results.
$\left.\mathrm{Pt}\left[\mathrm{CH}_{2} \mathrm{C}(\mathrm{Py}) \mathrm{CH}\right]\right\}\left(\mathrm{BF}_{4}\right)(\mathbf{2 c})$ in $91 \%$ yield based on NMR integration. When the solution of $\mathbf{2 c}$ was brought to $-20{ }^{\circ} \mathrm{C}$, another platinum complex that exhibits a characteristic $\eta^{1}$-allenyl signature was formed. The two $31 \mathrm{p}$ doublets at $\delta 8.36$ and 24.86 with J $\mathrm{p}-\mathrm{p}=16.4 \mathrm{~Hz}$ and $\mathrm{J}_{\mathrm{P}-\mathrm{pt}}=3662$ and $2113 \mathrm{~Hz}$, respectively, suggest that it is a cis square-planar complex. The pyridine signals were found to indicate coordination. We assign this product as cis-[Pt $\left.\left(\mathrm{PPh}_{3}\right)_{2}(\mathrm{Py})\left(\eta^{1}-\mathrm{CHCCH}_{2}\right)\right]\left(\mathrm{BF}_{4}\right)(3)$ accordingly. The relative abundance of $2 \mathrm{c}: 3: 1$ changed from 0.64:0.23:0.13 after 30 min to 0.57:0.30:0.14 after $8 \mathrm{~h}$. When the temperature of the solution was raised to $0{ }^{\circ} \mathrm{C}$ for $20 \mathrm{~min}$, the amount of complex $\mathbf{3}$ accounted for $85 \%$ of the starting amount of $\mathbf{1}$. Complexes $\mathbf{1}$ and 2c were not observed after that point, no matter how much the temperature was changed. Leaving $\mathbf{3}$ in solution at $25{ }^{\circ} \mathrm{C}$ caused the formation of a mixture of platinum complexes of $\eta^{3}$-2-hydroxyallyl and $\eta^{3}$-oxatrimethylenemethane and diplatina- $\eta^{6}$-diallyl ether. ${ }^{11}$ One may infer that $\mathbf{1}$ can undergo nucleophilic attack either at the central carbon to give $\mathbf{2 c}$ or at the metal center to give $\mathbf{3}$. Complex $\mathbf{2 c}$ is the kinetic product, and $\mathbf{3}$ is the thermodynamic product. Both products can revert to $\mathbf{1}$ by losing pyridine. The moisture that penetrated into the reaction vessel is blamed for hydrolyzing $\mathbf{1}$ to the hydroxyallyl complex and its ensuing byproducts of $\eta^{3}$-O-TMM and $\eta^{6}$-diallyl ether complexes (Scheme 4).

The reactions of other ( $\eta^{1}$-allenyl)platinum complexes such as trans-Pt $\left(\mathrm{PPh}_{3}\right)_{2}(\mathrm{Br})\left(\eta^{1}-\mathrm{CHCCH}_{2}\right)$ and $\mathrm{PPh}_{3}$ do not result in metallacycl obutene. The addition reaction of an octahedral ( $\eta^{1}$-allenyl)iridium complex, however, was observed. Stirring a mixture of (OC-6-42) $-\mathrm{Ir}(\mathrm{Cl})$ $\left(\mathrm{PPh}_{3}\right)_{2}(\mathrm{OTf})(\mathrm{CO})\left(\eta^{1}-\mathrm{CHCCH}_{2}\right)(4)^{12}$ and $\mathrm{PPh}_{3}$ at $-15^{\circ} \mathrm{C}$ for $30 \mathrm{~min}$ caused a color change from reddish brown to yellow. The iridacycl obutene complex $\left\{(\mathrm{Cl})\left(\mathrm{PPh}_{3}\right)_{2^{-}}\right.$

(CO) $\left.r\left[\mathrm{CH}_{2} \mathrm{C}\left(\mathrm{PPh}_{3}\right) \mathrm{CH}\right]\right\}$ (OTf) (5) was isolated in $78 \%$ yield (Scheme 5). The 31P NMR data indicate that two phosphine ligands in $\mathbf{5}$ are in a trans arrangement. The ${ }^{1} \mathrm{H}$ and ${ }^{13} \mathrm{C}$ NMR data of the metallacyclobutene moiety of $\mathbf{5}$ are consistent with those of $\mathbf{2} \mathbf{a}-\mathbf{c}$ and the documented iridacycl obutenes. ${ }^{7 i, j}$ The carbonyl ligand of $\mathbf{5}$ is evidenced by an IR band at $2035 \mathrm{~cm}^{-1}$ and a ${ }^{13} \mathrm{C} \mathrm{NMR}$ resonance at $\delta$ 171.5.

Single crystals of $\mathbf{5}$ were grown from a $\mathrm{CH}_{2} \mathrm{Cl}_{2} / \mathrm{Et}_{2} \mathrm{O}$ solution, and an X-ray diffraction study was carried out. An ORTEP drawing showing the molecular structure of $\mathbf{5}$ is depicted in Figure 1. The metallacycle moiety, $\mathrm{Pt}-\mathrm{C} 2-\mathrm{C} 3-\mathrm{C} 4-\mathrm{P} 1$, is quite coplanar, with the largest out-of-plane deviation at C3 being 0.04(2) $\AA$ and the mean deviation being $0.02 \AA ; X^{2}$ is 8.25. The length of $\mathrm{C2}-\mathrm{C} 3$ is consistent with a double bond, and $\mathrm{Ir}-\mathrm{C} 2\left(\mathrm{sp}^{2}\right)$ and $\mathrm{Ir}-\mathrm{C} 4\left(\mathrm{sp}^{3}\right)$ are in the single-bond re gion. Comparisons of important structural data be tween 5 and the closely related complex $(\mathrm{Br})\left(\mathrm{PMe}_{3}\right)_{3^{-}}$

$\operatorname{Ir}\left[\mathrm{CH}_{2} \mathrm{C}(\mathrm{p}-\mathrm{Tol}) \mathrm{C}(\mathrm{p}-\mathrm{Tol})\right]\left(\mathbf{5}^{\prime}\right)^{7 \mathrm{i}}$ are listed in Table 1, which show excellent consistency with each other and with other titana- ${ }^{4,5}$ platina- $, 7 \mathrm{~m}, \mathrm{n}$ and rhenacyclobutenes. ${ }^{8 \mathrm{~b}}$ Two val ence tautomers of metallacyclobutene, carbene

(11) Huang, T.-M.; Hsu, R.-H.; Yang, C.-S.; Chen, J .-T.; Lee, G.-H.; Wang, Y. Organometallics 1994, 13, 3657.

(12) (a) Hsu, R.-H.; Chen, J .-T.; Lee, G.-H.; Wang, Y. OrganometalIics 1997, 16, 1159. (b) Chen, J .-T.; Chen, Y.-K.; Chu, J .-B.; Lee, G.H.; Wang, Y. Organometallics 1997, 16, 1476. 


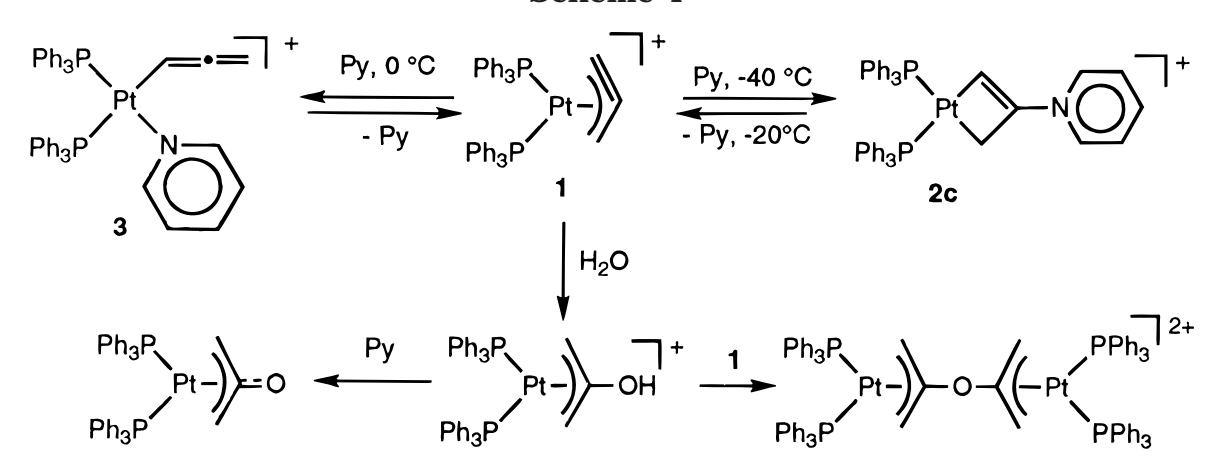

Scheme 5

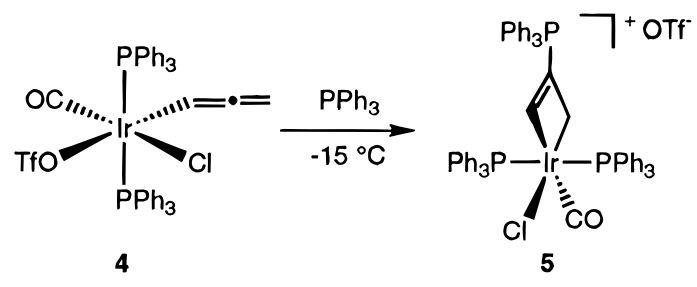

acetylene complexes (5) and $\eta^{3}$-vinylcarbene complexes (5c), have been structurally characterized. ${ }^{13,14}$ By judg-

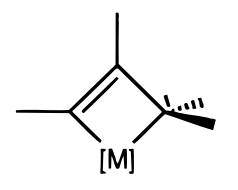

$5 \mathbf{a}$

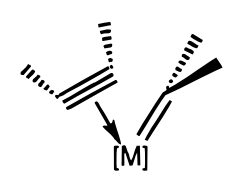

$5 \mathbf{b}$

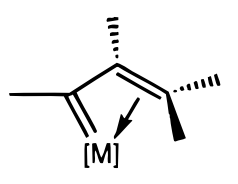

$5 c$ ing the X-ray data for $\mathbf{5}$ and for species $\mathbf{5 b}$ and $\mathbf{5 c}$, we unequivocally classify complex $\mathbf{5}$ to be the extreme form of metallacyclobutene, $\mathbf{5 a}$.

The reaction of $\mathbf{4}$ with pyridine, which is less bulky than $\mathrm{PPh}_{3}$, does not give a metallacycl obutene product. The replacement of pyridine for the triflate of $\mathbf{4}$, instead of addition of pyridine to the al lenyl ligand, takes place and gives (OC-6-42)- $\mathrm{Ir}(\mathrm{Cl})\left(\mathrm{PPh}_{3}\right)_{2}(\mathrm{Py})(\mathrm{CO})\left(\eta^{1}-\mathrm{CHCCH}_{2}\right)$ (6). ${ }^{12 \mathrm{~b}}$ Such a reactivity again supports the notion that the formation of metallacyclobutenes likely is due to external nucleophilic attack at the central carbon of an $\eta^{3}$-allenyl/propargyl ligand (Scheme 6). Metallacyclobutenes have been invoked as the kinetic intermediates of the formation of central-carbon-substituted $\eta^{3}$ allyl complexes from nucleophilic addition of $\eta^{1}$-allenyl and $\eta^{3}$-allenyl/propargyl complexes. ${ }^{8-11,15}$ A reaction resulting in the formation of $\left\{\mathrm{Pt}\left(\mathrm{PPh}_{3}\right)_{2}\left[\eta^{3}-\mathrm{CH}_{2} \mathrm{C}\left(\mathrm{PPh}_{3}\right)-\right.\right.$ $\left.\left.\mathrm{CH}_{2}\right]\right\}\left(\mathrm{BF}_{4}\right)_{2}$ (7) from protonation of $\mathbf{2} \mathbf{b}$ affords sound evidence for the former pathway (Scheme 7). On the other hand, insertion of coordinated allene into an $\mathrm{M}-\mathrm{L}$ bond also was considered to be a possibility. ${ }^{16}$

(13) (a) Foley, H. C.; Strubinger, L. M.; Targos, T. S.; Geoffroy, G. L. J . Am. Chem. Soc. 1983, 105, 3064.

(14) (a) Nakatsu, K.; Mitsudo, T.; Nakanishi, H.; Watanabe, Y.; Takegami, Y. Chem. Lett. 1977, 1447. (b) Klimes, J .; Weiss, E. Angew. Chem., Int. Ed. Engl. 1982, 21, 205. (c) Mayr, A.; Asaro, M. F.; Glines, T. J . J . Am. Chem. Soc. 1987, 109, 2215. (d) Garrett, K. E.; Sheridan, J. B.; Pourreau, D. B.; Feng, W. C.; Geoffroy, G. L.; Staley, D. L.; Rheingold, A. L. J . Am. Chem. Soc. 1989, 111, 8383. (e) Herrmann, W. A.; Fischer, R. A.; Herdtweck, E. Angew. Chem., Int. Ed. Engl. 1987, 26, 1263. (f) Fischer, R. A.; Fischer, R. W.; Herrmann, W. A.; Herdtweck, E. Chem. Ber. 1989, 122, 2035.

(15) Casey, C. P.; Chung, S.; Ha, Y.; Powell, D. R. Inorg. Chim. Acta 1997, 265, 127.

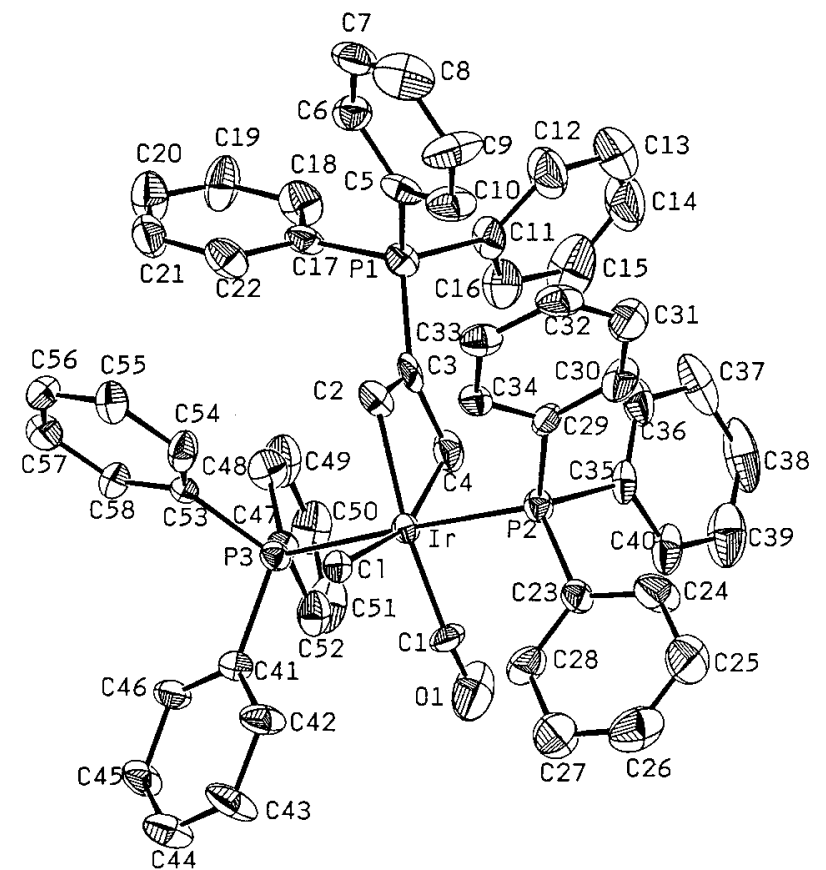

Figure 1. ORTEP drawing of $\left\{( \mathrm { Cl } ) ( \mathrm { PPh } _ { 3 } ) _ { 2 } ( \mathrm { CO } ) \longdiv { \mathrm { r } [ \mathrm { CH } _ { 2 } \mathrm { C } - }\right.$ $\left.\left.\overrightarrow{\left(\mathrm{PPh}_{3}\right) \mathrm{CH}}\right]\right\}$ (OTf) (5) with $50 \%$ probability ellipsoids. The hydrogen atoms and the anion are omitted for clarity.

Table 1. Bond Comparison of 5 and $5^{\prime}$

\begin{tabular}{lllll}
\hline \multicolumn{2}{c}{5} & & \multicolumn{2}{c}{$\mathbf{5}^{\prime}$} \\
\cline { 5 - 5 } Ir-C2 & $2.08(2)$ & & Ir-C1 & $2.134(5)$ \\
Ir-C4 & $2.23(2)$ & & Ir-C3 & $2.166(6)$ \\
C2-C3 & $1.39(2)$ & & C1-C2 & $1.344(8)$ \\
C3-C4 & $1.53(3)$ & & C2-C3 & $1.525(7)$ \\
C2-Ir-C4 & $66.9(7)$ & & C1-Ir-C3 & $64.5(2)$ \\
C2-C3-C4 & $109(2)$ & & C1-C2-C3 & $106.1(5)$ \\
Ir-C2-C3 & $97(1)$ & & $\mid r-C 1-C 2$ & $98.0(3)$ \\
Ir-C4-C3 & $87(1)$ & Ir-C3-C2 & $91.2(3)$
\end{tabular}

In conclusion, regioselective addition to the $\eta^{3}$-allenyl/ propargyl or $\eta^{1}$-allenyl complexes provides an alternative methodol ogy for the synthesis of metallacyd obutenes.

\section{Experimental Section}

General Considerations. Solvents were dried by standard procedures. IR spectra were recorded on a Bio-Rad FTS-

(16) (a) Cowan, R. L.; Trogler, W. C. Organometallics 1987, 6, 2451. (b) Allen, S. R.; Beevor, R. G.; Green, M.; Norman, N. C.; Orpen, A. G.; Williams, I. D. J . Chem. Soc., Dalton Trans. 1981, 2339. (c) Merola, J . S. Organometallics 1989, 8, 2975. (d) Wolf, J .; Werner, H. Organometallics 1987, 6, 1164. 
Scheme 6
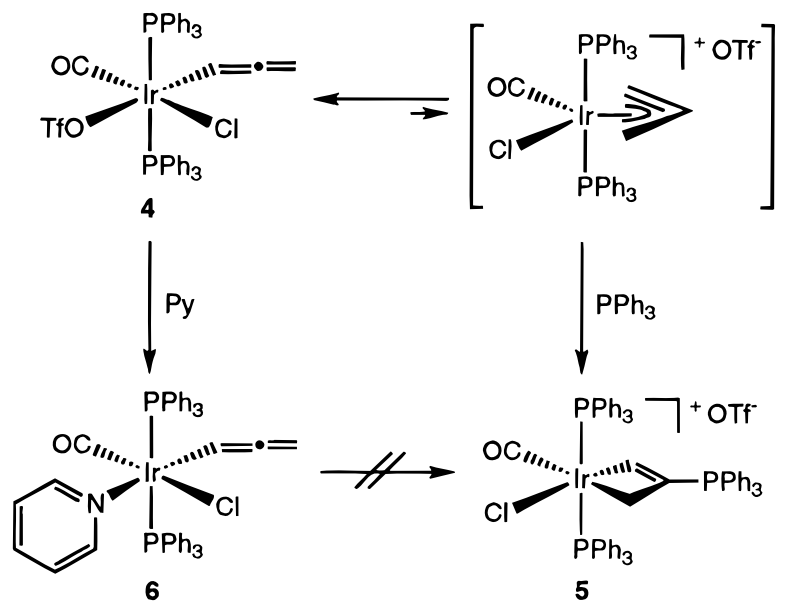

Scheme 7

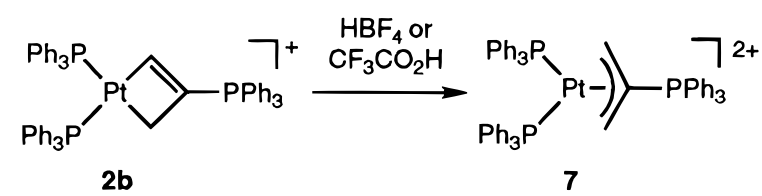

40 spectrophotometer. The NMR spectra were recorded on a Bruker AC-200 or a ACE-300 spectrometer. Spectrometer frequencies of 81.015 or $121.496 \mathrm{MHz}$ for ${ }^{31} \mathrm{P} \mathrm{NMR}, 200.133$ or $300.135 \mathrm{MHz}$ for ${ }^{1} \mathrm{H} \mathrm{NMR}$, and 50.323 or $75.469 \mathrm{MHz}$ for ${ }^{13} \mathrm{C}$ N MR spectra were employed. Mass spectrometric analyses were collected on a J E OL SX-102A spectrometer. Elemental analyses were done on a Perkin-EImer $2400 \mathrm{CHN}$ analyzer.

Synthesis and Characterization. cis- $\left\{\left(\mathrm{PPh}_{3}\right)_{2} \mathrm{Pt}\left[\mathrm{CH}_{2} \mathrm{C}-\right.\right.$

(NEt $\mathbf{A}_{3} \mathbf{C H}$ ] $\mathbf{B F}_{\mathbf{4}}$ ) (2a). A two-necked round-bottomed flask was charged with $1(45 \mathrm{mg}, 0.05 \mathrm{mmol})^{11}$ and dry $\mathrm{CDCl}_{3}(0.7$ $\mathrm{mL})$. Triethylamine ( $21 \mu \mathrm{L}, 0.05 \mathrm{mmol})$ was injected into the solution at $-40^{\circ} \mathrm{C}$. The conversion to $2 \mathrm{a}$ was quantitative on the basis of the NMR data. Attempted isolation of $\mathbf{2 a}$ by crystallization resulted in its decomposition even at $-20^{\circ} \mathrm{C}$. ${ }^{31} \mathrm{P}$ NMR $\left(\mathrm{CDCl}_{3}, 233 \mathrm{~K}, 81.015 \mathrm{MHz}\right): \delta 20.9$ (d with ${ }^{195} \mathrm{Pt}$ satellites, J p-p $=10.2 \mathrm{~Hz}$, J $\mathrm{p}-\mathrm{pt}=2470 \mathrm{~Hz}), 21.1$ (d with ${ }^{195} \mathrm{Pt}$ satellites, J $\left.\mathrm{p}-\mathrm{p}=10.2 \mathrm{~Hz}, \mathrm{~J}_{\mathrm{P}-\mathrm{Pt}}=2335 \mathrm{~Hz}\right) .{ }^{1} \mathrm{H} \mathrm{NMR}\left(\mathrm{CDCl}_{3}\right.$, $233 \mathrm{~K}, 200 \mathrm{MHz}): \delta 0.03\left(2 \mathrm{H}, \mathrm{m}\right.$ with ${ }^{195} \mathrm{Pt}$ coupling, J $\mathrm{H}-\mathrm{Pt}=$ $\left.81.9 \mathrm{~Hz}, \mathrm{PtCH}_{2}\right), 1.12\left(9 \mathrm{H}, \mathrm{t}, \mathrm{J} \mathrm{H}-\mathrm{H}=6.77 \mathrm{~Hz}, \mathrm{CH}_{2} \mathrm{CH}_{3}\right), 2.99$ $\left(6 \mathrm{H}, \mathrm{q}, \mathrm{J} \mathrm{H}-\mathrm{H}=6.77 \mathrm{~Hz}, \mathrm{NCH}_{2}\right), 6.01\left(1 \mathrm{H}, \mathrm{s}\right.$ with ${ }^{195} \mathrm{Pt}$ coupling, $\mathrm{J} H-\mathrm{Pt}=25.9 \mathrm{~Hz}, \mathrm{PtCH}), 7.1-7.3\left(30 \mathrm{H}, \mathrm{m}\right.$, phenyl H). ${ }^{13} \mathrm{C} \mathrm{NMR}$ $\left(\mathrm{CDCl}_{3}, 263 \mathrm{~K}, 50.323 \mathrm{MHz}\right): \delta-6.07\left(\mathrm{~d}, \mathrm{~J}_{\mathrm{c}-\mathrm{P}}=79.4, \mathrm{PtCH}_{2}\right)$, 7.36 (s, $\left.\mathrm{CH}_{2} \mathrm{CH}_{3}\right), 47.0$ (s, $\mathrm{NCH}_{2}$ ), 123.1 (dd, J c-p $=6.3,106.8$ $\mathrm{Hz}, \mathrm{PtCH}$ ), 127-134 (phenyl carbons), 142.2 (d with ${ }^{195} \mathrm{Pt}$ satellites, J $\mathrm{C}-\mathrm{p}=7.02 \mathrm{~Hz}$, J $\mathrm{C}-\mathrm{Pt}=96.5 \mathrm{~Hz}, \mathrm{CN}$ ).

cis- $\left.\left\{\left(\mathbf{P P h}_{3}\right)_{2} \mathbf{P t} \mathbf{C} \mathbf{C H}_{2} \mathbf{C}\left(\mathbf{P P h}_{3}\right) \mathbf{C H}\right]\right\}\left(\mathbf{B F}_{4}\right) \mathbf{( 2 b )}$. A two-necked round-bottomed flask was charged with $\left[\mathrm{Pt}\left(\mathrm{PPh}_{3}\right)_{2}\left(\eta^{3}-\mathrm{C}_{3} \mathrm{H}_{3}\right)\right]-$ $\left(\mathrm{BF}_{4}\right)(\mathbf{1} ; 1145 \mathrm{mg}, 0.05 \mathrm{mmol})$ and dry $\mathrm{CDCl}_{3}(1 \mathrm{~mL})$. Addition of triphenylphosphine ( $13 \mathrm{mg}, 0.05 \mathrm{mmol}$ ) to the solution at $-40{ }^{\circ} \mathrm{C}$ immediately resulted in the formation of $\mathbf{2 b}$. The solid product was isolated by crystallization at $0{ }^{\circ} \mathrm{C}$ from $\mathrm{C}_{6} \mathrm{H}_{6} / \mathrm{Et}_{2} \mathrm{O}$ in $83 \%$ yield $(48 \mathrm{mg})$. ${ }^{31} \mathrm{P} \mathrm{NMR}\left(\mathrm{CDCl}_{3}, 273 \mathrm{~K}, 121.496\right.$ $\mathrm{MHz}$ ): $\delta 8.2$ (dd with ${ }^{195} \mathrm{pt}$ coupling, J $\mathrm{p}-\mathrm{p}=38.6 \mathrm{~Hz}, 21.7 \mathrm{~Hz}$, $\mathrm{J}_{\mathrm{p}-\mathrm{pt}}=703.8 \mathrm{~Hz}$ ), 19.2 (dd with ${ }^{195} \mathrm{Pt}$ coupling, J $\mathrm{p}-\mathrm{p}=10.4$ $\mathrm{Hz}, 38.6 \mathrm{~Hz}$, J p-pt = $2226 \mathrm{~Hz}$ ), 22.4 (dd with ${ }^{195} \mathrm{Pt}$ coupling, $\mathrm{J}_{\mathrm{p}-\mathrm{p}}=10.4 \mathrm{~Hz}, 21.7 \mathrm{~Hz}$, J $\left.\mathrm{p}-\mathrm{pt}=2115 \mathrm{~Hz}\right) .{ }^{1} \mathrm{H} \mathrm{NMR}\left(\mathrm{CDCl}_{3}\right.$, $200 \mathrm{MHz}$ ): $\delta 0.18$ (dd with ${ }^{195} \mathrm{Pt}$ coupling, J $\mathrm{H}-\mathrm{H}=4.7 \mathrm{~Hz}, \mathrm{~J} \mathrm{H}-\mathrm{P}$ $\left.=4.4 \mathrm{~Hz}, \mathrm{~J} \mathrm{H}-\mathrm{Pt}=85.8 \mathrm{~Hz}, 2 \mathrm{H}, \mathrm{PtCH}_{2}\right), 7.35(\mathrm{PtCH}), 6.8-7.8$ $\left(\mathrm{m}\right.$, phenyl H ). ${ }^{13} \mathrm{C} \mathrm{NMR}\left(\mathrm{CDCl}_{3}, 263 \mathrm{~K}, 50.323 \mathrm{MHz}\right): \delta-12.6$ (d, J c-P $=83.5, \mathrm{PtCH}_{2}$ ), 127-134 (phenyl carbons), 136.3 (d, $\left.\mathrm{J}_{\mathrm{c}-\mathrm{P}}=38.6 \mathrm{~Hz}, \mathrm{CP}\right), 161.1\left(\mathrm{~d}, \mathrm{~J}_{\mathrm{c}-\mathrm{P}}=107.0 \mathrm{~Hz}, \mathrm{PtCH}\right)$. MS (FAB, m/z): $1020.5\left(\mathrm{M}^{+}-\mathrm{BF}_{4}\right)$. Anal. Calcd for $\mathrm{PtC}_{57} \mathrm{H}_{48} \mathrm{P}_{3^{-}}$ $\mathrm{BF}_{4}$ : $\mathrm{C}, 61.77 ; \mathrm{H}, 4.37$. Found: $\mathrm{C}, 60.85 ; \mathrm{H}, 4.42$.
Table 2. X-ray Crystal Parameters and Data Collection Details for 5

$\begin{array}{ll}\text { formula } & \mathrm{C}_{59} \mathrm{H}_{48} \mathrm{O}_{4} \mathrm{P}_{3} \mathrm{ClSF}_{3} \mathrm{Ir} \cdot 2.5 \mathrm{H}_{2} \mathrm{O} \\ \text { fw } & 1267.64 \\ \text { cryst dimns, mm } & 0.10 \times 0.15 \times 0.40 \\ \text { space group } & \mathrm{P} \overline{1} \\ \mathrm{a}, \AA & 10.063(5) \\ \mathrm{b}, \AA & 12.821(1) \\ \mathrm{C}, \AA & 22.353(3) \\ \alpha, \text { deg } & 102.57(1) \\ \beta, \text { deg } & 99.93(3) \\ \gamma, \text { deg } & 97.12(3) \\ \mathrm{V}, \AA^{3} & 2733(1) \\ \mathrm{Z} & 2 \\ \rho(\text { calcd), Mg m } & \\ \mathrm{F}(000) & 1.540 \\ \text { radiation; } \lambda, \AA & 1264 \\ \mathrm{~T}, \mathrm{~K} & \mathrm{MoK} \alpha ; 0.7107 \\ \mu, \mathrm{mm}{ }^{-1} & 298 \\ \text { transmission } & 2.57 \\ \text { max } 2 \theta, \text { deg } & 0.83-1.0 \\ \mathrm{~h}, \mathrm{k}, \mathrm{I} & 45 \\ \text { no. of rflns measd } & \pm 10,13, \pm 24 \\ \text { no. of rflns obsd } & 7145 \\ \text { no. of variables } & 4551(>2.0 \sigma) \\ \mathrm{R}(\mathrm{F}) & 587 \\ \mathrm{R}(\mathrm{F}) & 0.059 \\ \mathrm{~S} & 0.059 \\ (\Delta / \sigma)_{\text {max }} & 1.88 \\ & 0.0138 \\ & \end{array}$

Table 3. Selected Bond Distances ( $(\AA)$ and Angles (deg) for 5

\begin{tabular}{llllll}
\hline $\mathrm{Ir}-\mathrm{Cl}$ & $2.502(4)$ & $\mathrm{Ir}-\mathrm{P} 2$ & $2.383(4)$ & $\mathrm{Ir}-\mathrm{P} 3$ & $2.377(4)$ \\
$\mathrm{Ir}-\mathrm{C} 1$ & $1.91(2)$ & $\mathrm{Ir}-\mathrm{C} 2$ & $2.08(2)$ & $\mathrm{Ir}-\mathrm{C} 4$ & $2.23(2)$ \\
$\mathrm{C} 1-\mathrm{O} 1$ & $1.00(2)$ & $\mathrm{C} 2-\mathrm{C} 3$ & $1.39(2)$ & $\mathrm{C} 3-\mathrm{C} 4$ & $1.53(3)$ \\
$\mathrm{C} 3-\mathrm{P} 1$ & $1.83(2)$ & & & &
\end{tabular}

$\mathrm{Cl}-\mathrm{Ir}-\mathrm{P} 2 \quad$ 90.(1) $\mathrm{Cl}-\mathrm{Ir}-\mathrm{P} 3 \quad$ 89.8(1) $\mathrm{Cl}-\mathrm{Ir}-\mathrm{Cl} \quad$ 100.9(7) $\mathrm{Cl}-\mathrm{Ir}-\mathrm{C} 2 \quad 93.7(5) \mathrm{Cl}-\mathrm{Ir}-\mathrm{C} 4 \quad 160.6(5) \mathrm{P} 2-\mathrm{Ir}-\mathrm{P} 3 \quad 177.9(2)$

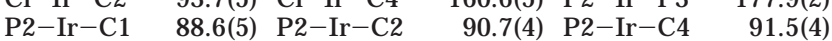
$\mathrm{P} 3-\mathrm{Ir}-\mathrm{C} 1 \quad 89.5(5) \mathrm{P} 3-\mathrm{Ir}-\mathrm{C} 2 \quad 91.3(4) \mathrm{P} 3-\mathrm{Ir}-\mathrm{C} 4 \quad 89.4(4)$ $\mathrm{C} 1-\mathrm{Ir}-\mathrm{C} 2 \quad 165.4(8) \mathrm{C} 1-\mathrm{Ir}-\mathrm{C} 4 \quad 98.5(8) \quad \mathrm{C} 2-\mathrm{Ir}-\mathrm{C} 4 \quad 66.9(7)$ C3-P1-C5 110.8(8) C3-P1-C11 107.8(8) C3-P1-C17 112.0(7) $\mid \mathrm{r}-\mathrm{C} 1-\mathrm{O} 1 \mathrm{172}(2) \quad \mathrm{Ir}-\mathrm{C} 2-\mathrm{C} 3$ 97(1) $\mathrm{P} 1-\mathrm{C} 3-\mathrm{C} 2 \quad 120(1)$ P1-C3-C4 131(1) C2-C3-C4 109(2) Ir-C4-C3 87(1)

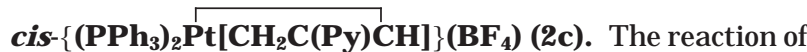
$1(45 \mathrm{mg}, 0.05 \mathrm{mmol})$ and pyridine $(4.0 \mu \mathrm{L}, 0.05 \mathrm{mmol})$ in $\mathrm{CDCl}_{3}(0.7 \mathrm{~mL})$ at $-40{ }^{\circ} \mathrm{C}$ produced $2 \mathrm{c}$ in $91 \%$ yield based on the NMR data. ${ }^{31} \mathrm{P} \mathrm{NMR}\left(\mathrm{CDCl}_{3}, 233 \mathrm{~K}, 121.496 \mathrm{MHz}\right): \delta$ 19.6 (d with ${ }^{195} \mathrm{pt}$ coupling, J p-p $=12.72 \mathrm{~Hz}$, J p-pt $=2445 \mathrm{~Hz}$ ), 21.6 (d with ${ }^{195} \mathrm{Pt}$ coupling, J $\mathrm{p}-\mathrm{p}=12.72 \mathrm{~Hz}$, J $\mathrm{p}-\mathrm{pt}=2332 \mathrm{~Hz}$ ). ${ }^{1} \mathrm{H} \mathrm{NMR}\left(\mathrm{CDCl}_{3}, 233 \mathrm{~K}, 200 \mathrm{MHz}\right): \delta 0.47\left(2 \mathrm{H}, \mathrm{m}\right.$ with ${ }^{195} \mathrm{Pt}$ coupling, J $\left.\mathrm{H}-\mathrm{Pt}=80.4 \mathrm{~Hz}, \mathrm{PtCH}_{2}\right), 6.73\left(1 \mathrm{H}\right.$, s with ${ }^{195} \mathrm{Pt}$ coupling, J H-Pt $=24.6 \mathrm{~Hz}, \mathrm{PtCH}), 6.8-7.3(\mathrm{~m}$, phenyl $\mathrm{H}), 8.03$ $\left(2 \mathrm{H}, \mathrm{m}, \mathrm{o}-\mathrm{H}_{\mathrm{Py}}\right), 8.40\left(\mathrm{H}, \mathrm{m}, \mathrm{p}-\mathrm{H}_{\mathrm{Py}}\right) .{ }^{13} \mathrm{C} \mathrm{NMR}\left(\mathrm{CDCl}_{3}, 233 \mathrm{~K}\right.$, $50.32 \mathrm{MHz}): \delta-4.89\left(\mathrm{~d}, \mathrm{~J}_{\mathrm{c}-\mathrm{p}}=78.4, \mathrm{PtCH}_{2}\right), 123.7\left(\mathrm{~d}, \mathrm{~J}_{\mathrm{c}-\mathrm{p}}=\right.$ 8.32, $151.7 \mathrm{~Hz}, \mathrm{PtCH}$ ), 123.75 (s, m- $\left.\mathrm{CPy}_{\mathrm{Py}}\right), 127-134.5$ (phenyl C), $136.4\left(\mathrm{~s}, \mathrm{p}-\mathrm{C}_{\mathrm{Py}}\right), 143.6\left(\mathrm{~d}, \mathrm{~J}_{\mathrm{C}-\mathrm{p}}=7.76 \mathrm{~Hz}, \mathrm{C}_{\mathrm{Py}}\right), 144.8(\mathrm{~s}$, $\left.\mathrm{o}-\mathrm{C}_{\mathrm{Py}}\right)$.

cis-[Pt $\left.\left(\mathbf{P P h}_{3}\right)_{2}\left(\eta^{1}-\mathbf{C H C C H}_{2}\right)(\mathbf{P y})\right]\left(\mathbf{B F}_{4}\right)$ (3). The temperature of a solution of $2 \mathrm{c}$, first at $-40^{\circ} \mathrm{C}$, was raised to $0{ }^{\circ} \mathrm{C}$ for $20 \mathrm{~min}$, which gave $\mathbf{3}$ in $85 \%$ yield based on the NMR data. 31P NMR $\left(\mathrm{CDCl}_{3}, 273 \mathrm{~K}, 121.496 \mathrm{MHz}\right): \delta 8.36$ (d with ${ }^{195 \mathrm{Pt}}$ coupling, J $p-p=16.4 \mathrm{~Hz}$, J p-pt $=3662 \mathrm{~Hz}$ ), 24.86 (d with ${ }^{195} \mathrm{Pt}$ coupling, J $\mathrm{p}-\mathrm{p}=16.4 \mathrm{~Hz}$, J $\left.\mathrm{p}-\mathrm{pt}=2113 \mathrm{~Hz}\right) .{ }^{1} \mathrm{H} \mathrm{NMR}$ $\left(\mathrm{CDCl}_{3}, 273 \mathrm{~K}, 200 \mathrm{MHz}\right): \delta 3.48\left(2 \mathrm{H}, \mathrm{m}, \mathrm{CH}_{2}\right), 5.02(1 \mathrm{H}, \mathrm{m}$ with ${ }^{195} \mathrm{Pt}$ coupling, J $\left.\mathrm{H}-\mathrm{Pt}=47.2 \mathrm{~Hz}, \mathrm{CH}\right), 6.8-7.8(33 \mathrm{H}, \mathrm{m}$, phenyl $\mathrm{H}, \mathrm{Py}), 8.37\left(2 \mathrm{H}, \mathrm{m}, \mathrm{o}-\mathrm{H}_{\mathrm{Py}}\right) .{ }^{13} \mathrm{C} \mathrm{NMR}\left(\mathrm{CDCl}_{3}, 273 \mathrm{~K}\right.$, $50.323 \mathrm{MHz}$ ): $\delta 67.4\left(\mathrm{~d}, \mathrm{~J}_{\mathrm{c}-\mathrm{p}}=8.2 \mathrm{~Hz}, \mathrm{CH}_{2}\right), 88.1\left(\mathrm{dd}, \mathrm{J}_{\mathrm{c}-\mathrm{p}}=\right.$ $10.24,93.6 \mathrm{~Hz}, \mathrm{CH}$ ), $127-135$ (phenyl C), 126.0 (s, p-Cpy), 138.3 $\left(\mathrm{s}, \mathrm{m}-\mathrm{C}_{\mathrm{Py}}\right), 151.0\left(\mathrm{~s}, \mathrm{o}-\mathrm{C}_{\mathrm{Py}}\right), 205.5(\mathrm{~s},=\mathrm{C}=)$.

$\left\{(\mathbf{C l})\left(\mathbf{P P h}_{3}\right)_{2}(\mathbf{C O}) \mid \mathbf{r}\left[\mathrm{CH}_{2} \mathbf{C}\left(\mathbf{P P h}_{3}\right) \mathbf{C H}\right]\right\}$ (OTf) (5). To a twonecked round-bottomed flask was charged with $\mathbf{4}(200 \mathrm{mg}, 0.22$ 
mmol $)^{12}$ and $\mathrm{PPh}_{3}(67 \mathrm{mg}, 0.25 \mathrm{mmol})$, and the $\mathrm{CH}_{2} \mathrm{Cl}_{2}(15 \mathrm{~mL})$ was vacuum-transferred. The reaction solution was stirred at $-15{ }^{\circ} \mathrm{C}$ for $30 \mathrm{~min}$. The resulting yellow solution was concentrated, and the product was precipitated by adding hexane to give 5 in $78 \%$ yield $(215 \mathrm{mg})$. I R ( $\mathrm{KBr}$ pellet): $v_{\mathrm{CO}}$ $2035 \mathrm{~cm}^{-1}$. 31P NMR $\left(\mathrm{CDCl}_{3}, 121.496 \mathrm{MHz}\right): \delta-5.33,3.23$ $\left(d, d, J_{p-p}=3.65 \mathrm{~Hz}\right) .{ }^{1} \mathrm{H} N M R\left(\mathrm{CDCl}_{3}, 200 \mathrm{MHz}\right): \delta 1.70(2 \mathrm{H}$, $\left.\mathrm{t}, \mathrm{J}_{\mathrm{H}-\mathrm{P}}=5 \mathrm{~Hz}, \mathrm{PtCH}_{2}\right), 6.6-7.7(35 \mathrm{H}, \mathrm{m}$, phenyl $\mathrm{H}) .{ }^{13} \mathrm{C} \mathrm{NMR}$ $\left(\mathrm{CDCl}_{3}, 75.469 \mathrm{MHz}\right): \delta-5.49\left(\mathrm{t}, \mathrm{J}_{\mathrm{C}-\mathrm{P}}=6.38 \mathrm{~Hz}, \mathrm{PtCH}_{2}\right)$, $118.16\left(\mathrm{~d}, \mathrm{~J} \mathrm{c}-\mathrm{P}=85.1 \mathrm{~Hz}\right.$, i pso-C of $\left.\mathrm{CPPh}_{3}\right), 122.8(\mathrm{td}, \mathrm{J} \mathrm{c}-\mathrm{P}=$ 8.15, 38.4 Hz, CPPh $\left.{ }_{3}\right), 128-135$ (phenyl C), 146.0 (t, J c-p = $5.93 \mathrm{~Hz}, \mathrm{PtCH}), 171.5\left(\mathrm{t}, \mathrm{J}_{\mathrm{C}-\mathrm{P}}=8.19 \mathrm{~Hz}, \mathrm{CO}\right)$. MS (FAB, $\mathrm{m} / \mathrm{z}): 1230.30\left(\mathrm{M}^{+}\right), 1081.40\left(\mathrm{M}^{+}-\mathrm{OTf}\right)$. Anal. Calcd for I $\mathrm{rC}_{59} \mathrm{H}_{48} \mathrm{O}_{4} \mathrm{~F}_{3} \mathrm{P}_{3} \mathrm{SCl} \cdot 2.5 \mathrm{H}_{2} \mathrm{O}: \mathrm{C}, 55.57 ; \mathrm{H}, 4.19$. Found: C, 56.42; H, 4.01.

$\left\{\mathbf{P t}\left(\mathbf{P P h}_{\mathbf{3}}\right)_{2}\left[\eta^{\mathbf{3}}-\mathbf{C H}_{\mathbf{2}} \mathbf{C}\left(\mathbf{P P h}_{\mathbf{3}}\right) \mathbf{C H}_{\mathbf{2}}\right]\right\}\left(\mathbf{B F}_{\mathbf{4}}\right)_{\mathbf{2}}$ (7). To a $\mathrm{CDCl}_{3}$ solution $(0.5 \mathrm{~mL}$ ) containing $\mathbf{2 b}$ (30 $\mathrm{mg}, 0.059 \mathrm{mmol})$ was added an equimolar amount of $\mathrm{HBF}_{4} /$ etherate or $\mathrm{CF}_{3} \mathrm{CO}_{2} \mathrm{H}$ at $25^{\circ} \mathrm{C}$. The conversion to 7 was over $90 \%$ based on the NMR data. 31P NMR $\left(\mathrm{CDCl}_{3}, 121.496 \mathrm{MHz}\right): \delta 11.1(\mathrm{~J}-\mathrm{Pt}=4027 \mathrm{~Hz})$, $17.1(\mathrm{f}-\mathrm{Pt}=69.3 \mathrm{~Hz}) .{ }^{1} \mathrm{H} \mathrm{NMR}\left(\mathrm{CDCl}_{3}, 300 \mathrm{MHz}\right): \delta 3.46$ $(2 \mathrm{H}$, ddd, J $\mathrm{H}-\mathrm{H}=1.5 \mathrm{~Hz}$, J $\mathrm{H}-\mathrm{P}=1.5,12.1 \mathrm{~Hz}$ syn- $\mathrm{H}), 4.63(2 \mathrm{H}$, ddd, J $\mathrm{H}_{-\mathrm{H}}=1.5 \mathrm{~Hz}$, J $\mathrm{H}_{-\mathrm{P}}=6.1,29.9 \mathrm{~Hz}, \mathrm{~J}_{\mathrm{H}-\mathrm{Pt}}=47.1 \mathrm{~Hz}$, anti$\mathrm{H}), 7.0-8.0(35 \mathrm{H}, \mathrm{m}$, phenyl $\mathrm{H}) .{ }^{13} \mathrm{C} \mathrm{NMR}\left(\mathrm{CDCl}_{3}, 125.773\right.$ $\mathrm{MHz}$ ): $\delta 74.8$ (dd, J $\mathrm{c}-\mathrm{p}=5,14,38 \mathrm{~Hz}, \mathrm{~J}_{\mathrm{c}-\mathrm{Pt}} \approx 35 \mathrm{~Hz}, \mathrm{C}_{\mathrm{t}}$ ), 117.9 (d, J c-p $=87 \mathrm{~Hz}, \mathrm{C}_{\mathrm{c}}$ ), 128-135 (phenyl C).

X-ray Crystallographic Analysis. Diffraction data were measured at $298 \mathrm{~K}$ on a Nonius CAD-4 diffractometer with graphite-monochromatized MoK $\alpha$ radiation. Cell parameters were determined by a least-squares fit on 25 reflections. Intensity data were corrected for absorption on the basis of an experimental $\psi$ rotation curve. The refinement procedure was by a full-matrix least-squares method including all the non-hydrogen atoms anisotropically. Hydrogen atoms were fixed at the ideal geometry and a $\mathrm{C}-\mathrm{H}$ distance of $1.0 \AA$; their isotopic thermal parameters were fixed to the values of the attached carbon atoms at the convergence of the isotropic refinement. Atomic scattering factors were taken from ref 17. Computing programs are from the NRCC SDP VAX package. ${ }^{18}$ Crystallographic data and selected bond parameters of $\mathbf{5}$ are collected in Tables 2 and 3, respectively. Other detailed data are supplied in the Supporting Information.

Acknowledgment. We thank the National Science Council, Taiwan, ROC, for financial support.

Supporting Information Available: Tables giving the complete crystal parameters and data collection details, atomic coordinates and isothermal data, and bond lengths $(\AA)$ and angles (deg) for complex $\mathbf{5}$ and figures giving the N MR spectra of $\mathbf{2 a}-\mathbf{c}, \mathbf{3}$, and $\mathbf{7}$ (24 pages). Ordering information is given on any current masthead page.

\section{OM9708642}

(17) International Tables for X-ray Crystallography; Kynoch Press: Birmingham, England, 1974; Vol. IV.

(18) NRC VAX: Gabe, E.J .; LePage, Y.; Charland, J .-P.; Lee, F. L.; White, P. S. J . Appl. Crystallogr. 1989, 22, 384. 